Article

\title{
Integrin $\alpha 7$ and Extracellular Matrix Laminin 211 Interaction Promotes Proliferation of Acute Myeloid Leukemia Cells and Is Associated with Granulocytic Sarcoma
}

\author{
Nobuhiko Kobayashi $\left.{ }^{1}{ }^{(}\right)$, Tsukasa Oda ${ }^{2}{ }^{\circledR}$, Makiko Takizawa ${ }^{1}$, Takuma Ishizaki ${ }^{1}$, \\ Norifumi Tsukamoto $^{3}$, Akihiko Yokohama ${ }^{4}$, Hisashi Takei ${ }^{1}$, Takayuki Saitoh ${ }^{5}$, \\ Hiroaki Shimizu ${ }^{1}$, Kazuki Honma ${ }^{5}$, Kei Kimura-Masuda ${ }^{5}$, Yuko Kuroda ${ }^{5}$, Rei Ishihara ${ }^{5}$, \\ Yuki Murakami ${ }^{5}$, Hirokazu Murakami ${ }^{5}$ and Hiroshi Handa ${ }^{1, *(D)}$ \\ 1 Department of Hematology, Gunma University Graduate School of Medicine, Maebashi 371-8510, Japan; \\ m15702046@gunma-u.ac.jp (N.K.); takizawm@gunma-u.ac.jp (M.T.); itakuma@gunma-u.ac.jp (T.I.); \\ m14702054@gunma-u.ac.jp (H.T.); hiroakis@gunma-u.ac.jp (H.S.) \\ 2 Laboratory of Molecular Genetics, The Institute for Molecular and Cellular Regulation, Gunma University, \\ Maebashi 371-8510, Japan; toda@gunma-u.ac.jp \\ 3 Oncology Center, Gunma University Hospital, Maebashi 371-8510, Japan; tsukamoto@gunma-u.ac.jp \\ 4 Blood Transfusion Service, Gunma University Hospital, Maebashi 371-8510, Japan; ayoko@gunma-u.ac.jp \\ 5 Graduate school of Health Science, Gunma University, Maebashi 371-8510, Japan; \\ tsaitoh@gunma-u.ac.jp (T.S.); m12203035@gunma-u.ac.jp (K.H.); m14711024@gunma-u.ac.jp (K.K.-M.); \\ m14711022@gunma-u.ac.jp (Y.K.); m13203005@gunma-u.ac.jp (R.I.); m13203034@gunma-u.ac.jp (Y.M.); \\ hmura@gunma-u.ac.jp (H.M.) \\ * $\quad$ Correspondence: handahiroshi@gunma-u.ac.jp; Tel.: +81-27-220-8166; Fax: +81-27-220-8173
}

Received: 4 December 2019; Accepted: 21 January 2020; Published: 5 February 2020

\begin{abstract}
Acute myeloid leukemia (AML) with granulocytic sarcoma (GS) is characterized by poor prognosis; however, its underlying mechanism is unclear. Bone marrow samples from 64 AML patients (9 with GS and 55 without GS) together with AML cell lines PL21, THP1, HL60, Kasumi-1, and KG-1 were used to elucidate the pathology of AML with GS. RNA-Seq analyses were performed on samples from seven AML patients with or without GS. Gene set enrichment analyses revealed significantly upregulated candidates on the cell surface of the GS group. Expression of the adhesion integrin $\alpha 7$ (ITGA7) was significantly higher in the GS group, as seen by RT-qPCR ( $p=0.00188$ ) and immunohistochemistry of bone marrow formalin-fixed, paraffin-embedded (FFPE) specimens. Flow cytometry revealed enhanced proliferation of PL21 and THP1 cells containing surface ITGA7 in the presence of laminin 211 and stimulated ERK phosphorylation; this effect was abrogated following ITGA7 knockdown or ERK inhibition. Overall, high ITGA7 expression was associated with poor patient survival ( $p=0.0477)$. In summary, ITGA7 is highly expressed in AML with GS, and its ligand (laminin 211) stimulates cell proliferation through ERK signaling. This is the first study demonstrating the role of integrin $\alpha 7$ and extracellular matrix interactions in AML cell proliferation and extramedullary disease development.
\end{abstract}

Keywords: acute myelogenous leukemia; granulocytic sarcoma; integrin; laminin; extracellular matrix

\section{Introduction}

Acute myelogenous leukemia (AML) is a hematopoietic malignancy, the prognosis of which remains poor despite intensive chemotherapy or allogeneic stem cell transplantation combined with advanced supportive care [1,2] The WHO classification, based primarily on genetic findings, has 
replaced the previous FAB classification, and WHO treatment strategy and outcome prediction are broadly accepted [3,4]. However, further predictors of prognosis are required to ensure an optimal treatment strategy for AML patients.

We previously reported on the poor prognosis of AML with granulocytic sarcoma (GS) at diagnosis [5,6]. GS is an extramedullary disease, whereby leukemic cells form a mass outside the bone marrow and often emerge at the time of relapse and/or progression of AML, as well as at diagnosis [6]. Although the precise mechanism responsible for development of GS has not been fully characterized, type IV collagenase has been found to promote invasion of AML cells throughout the basement membrane, leading to GS development [7]. Considering the prognostic value of GS, clarifying its underlying mechanism(s) may prove useful for identifying novel therapeutic targets as well as improving the prognosis.

Recently, increasing attention has been paid to examining the role that interactions between cancer cells and their microenvironment, including the extracellular matrix (ECM) and stroma cells, play in carcinogenesis [8-12]. Integrins are receptors present on the cell surface that react with the ECM. By mediating intracellular signaling, they are involved in cell proliferation, cell adhesion, and cytoskeleton formation [13]. Integrins form dimers of $\alpha$ and $\beta$ subunits and transduce various intracellular signals $[8,14]$. The ECM laminins serve as ligands for integrins with isoform-specific affinities. For example, laminin 211 has relatively high affinity for integrin $\alpha 7 \beta 1$ and the ensuing interaction transduces intracellular signals [8], including those beginning with the phosphorylation of focal adhesion kinase (FAK) and leading to the mitogen-activated protein kinase (MAPK)/ERK pathway, as well as the pathway initiated by binding of caveolin to Shc [14-16]. Several studies have shown that integrin $\alpha 4 \beta 1$, designated as very late antigen-4 (VLA-4), is highly expressed in AML cells. Further, cellular signaling via integrin and ECM binding has been described as playing important roles in AML progression, and hence, in overall disease prognosis [17-20]. However, the structural interactions that occur between integrins and the extracellular matrix to promote AML development have not been fully elucidated [21-27]

This study investigated the role of integrin $\alpha 7$ (ITGA7) in AML cells, focusing on its interaction with the ECM. The results demonstrate that ITGA7 expression is a prognostic predictor for AML and suggest a novel mechanism for AML progression.

\section{Results}

\subsection{Comprehensive Gene Expression Analysis of AML Cells by RNA-Seq}

To evaluate the differential expression of genes in AML with or without GS, we first performed comprehensive gene expression analysis of bone marrow specimens obtained from patients with AML with GS ( $n=7)$ or without GS $(n=7)$, respectively (Table S1). The RNA-Seq gene expression data of these two groups were analyzed by Cufflinks on Basespace supplied by Illumina. Gene set enrichment analysis (GSEA) revealed a significantly different expression of cell surface molecules compared with the control group (Figure 1a) [28]. Based on the GSEA data, we selected ITGA7 because the interaction between this integrin on leukemic cells and the ECM has not yet been studied but is speculated to play a role, especially in GS where leukemic cells are surrounded by a microenvironment different from the bone marrow (Figure 1b). ITGA7 gene expression in AML was confirmed by The Cancer Genome Atlas (TCGA) (Figure S1). The gene expression of integrin $\beta 1$, which pairs integrin $\alpha$ subunits, was also confirmed by our data (Figure S2). 
a

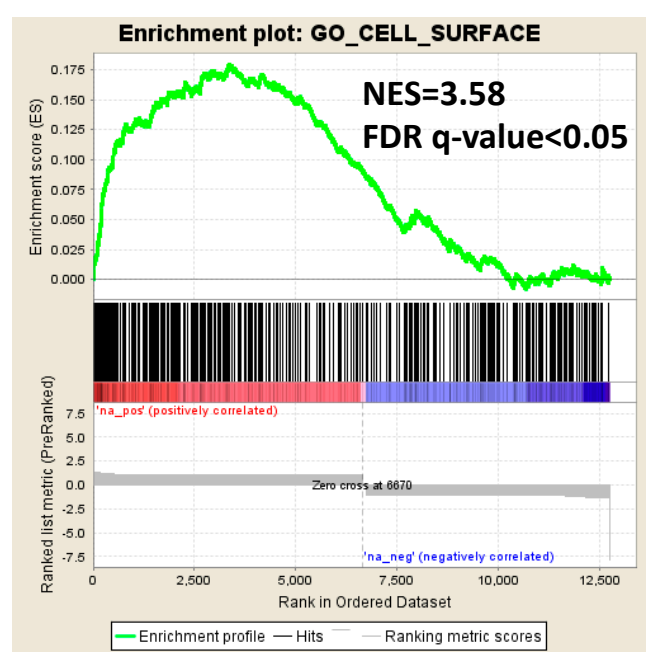

b

$\begin{array}{llcccc}\text { NAME } & \text { PROBE } & \text { RANK IN GENE LIST } & \text { RANK METRIC SCORE } & \text { RUNNING ES } & \text { CORE ENRIC } \\ \text { row_0 } & \text { ANXA5 } & 3 & 1.380755901 & 0.002783769 & \text { Yes } \\ \text { row_1 } & \text { CCR1 } & 12 & 1.380755901 & 0.005162548 & \text { Yes } \\ \text { row_2 } & \text { CD36 } & 16 & 1.380755901 & 0.007946316 & \text { Yes } \\ \text { row_3 } & \text { CD93 } & 17 & 1.380755901 & 0.010973078 & \text { Yes } \\ \text { row_4 } & \text { CDH5 } & 19 & 1.380755901 & 0.013918843 & \text { Yes } \\ \text { row_5 } & \text { HLA-DRB5 } & 37 & 1.380755901 & 0.015568641 & \text { Yes } \\ \text { row_6 } & \text { ITGA7 } & 40 & 1.380755901 & 0.018433407 & \text { Yes } \\ \text { row_7 } & \text { SORT1 } & 64 & 1.380755901 & 0.019597217 & \text { Yes } \\ \text { row_8 } & \text { TEK } & 90 & 1.366030693 & 0.020566754 & \text { Yes } \\ \text { row_9 } & \text { CD109 } & 94 & 1.358352423 & 0.023301411 & \text { Yes } \\ \text { row_10 } & \text { C5AR1 } & 100 & 1.352069378 & 0.0258603 & \text { Yes }\end{array}$

Figure 1. Gene expression in the acute myelogenous leukemia (AML) with granulocytic sarcoma (GS) group vs. AML without GS group. (a) Gene set enrichment analysis (GSEA) indicates that cell surface gene sets are enriched in AML with GS compared with AML without GS. Normalized enrichment scores (NES) and false discovery rate (FDR) $q$-values are given for the gene set. (b) List of genes enriched in the cell surface gene set derived from Gene Ontology annotations in GSEA (http://software.broadinstitute.org/gsea/msigdb/collection_details.jsp\#C5) (Collection 5). The order of genes is ranked according to the running enrichment score.

\subsection{ITGA7 Is Expressed in Both AML Patients and Cell Lines}

Next, we examined ITGA7 expression in bone marrow samples from 64 AML patients (9 with GS and 55 without GS), whose demographics are summarized in Table 1. Reverse-transcription quantitative polymerase chain reaction (RT-qPCR) revealed that ITGA7 expression was significantly higher in AML patients with GS compared with those without GS ( $p=0.00188$ ) (Figure 2a). ITGA7 expression was also confirmed in the GS formalin-fixed, paraffin-embedded (FFPE) tissue sections $(n=5)$ (Figure $2 b)$.

Table 1. Patient characteristics of the 64 AML study participants.

\begin{tabular}{cccc}
\hline & & With GS & Without GS \\
\hline Number of patients & & 9 & 55 \\
Age (median) & & $59(33-82)$ & $65(21-86)$ \\
White blood cells $(\mu \mathrm{L})$ & & $14750(2100-91,800)$ & $4800(700-205,800)$ \\
Blasts in peripheral blood (\%) & & $46.0(0-99)$ & $18.0(0-99)$ \\
Blasts in bone marrow (\%) & Favorable & $56.3(32-85.2)$ & $49.0(13-99)$ \\
& Intermediate & $1(11.1)$ & $8(14.6)$ \\
Karyotype risk (\%) & Adverse & $5(56.6)$ & $25(45.4)$ \\
& N.A. & $3(33.3)$ & $21(38.1)$ \\
& + & - & $1(1.8)$ \\
Chemotherapy & - & $9(100.0)$ & $43(78.1)$ \\
& Unknown & $0(0.0)$ & $8(14.6)$ \\
& Complete Remission & - & $4(7.3)$ \\
Response & (CR) & $7(77.8)$ & $20(46.5)$ \\
& Non-CR & $2(22.2)$ & $19(44.1)$ \\
& Unknown & - & $4(9.3)$ \\
\hline
\end{tabular}

The cell membranes and nuclei of atypical leukemic cells were immunohistochemically stained in FFPE specimens of bone marrow clots and GS. Both were positive for integrin $\alpha 7$ in cases with high expression of ITGA7 mRNA (Figure 2c,d). Flow cytometric analysis in AML samples confirmed the presence of integrin $\alpha 7$ on the cell surface (Figure S3). 
a

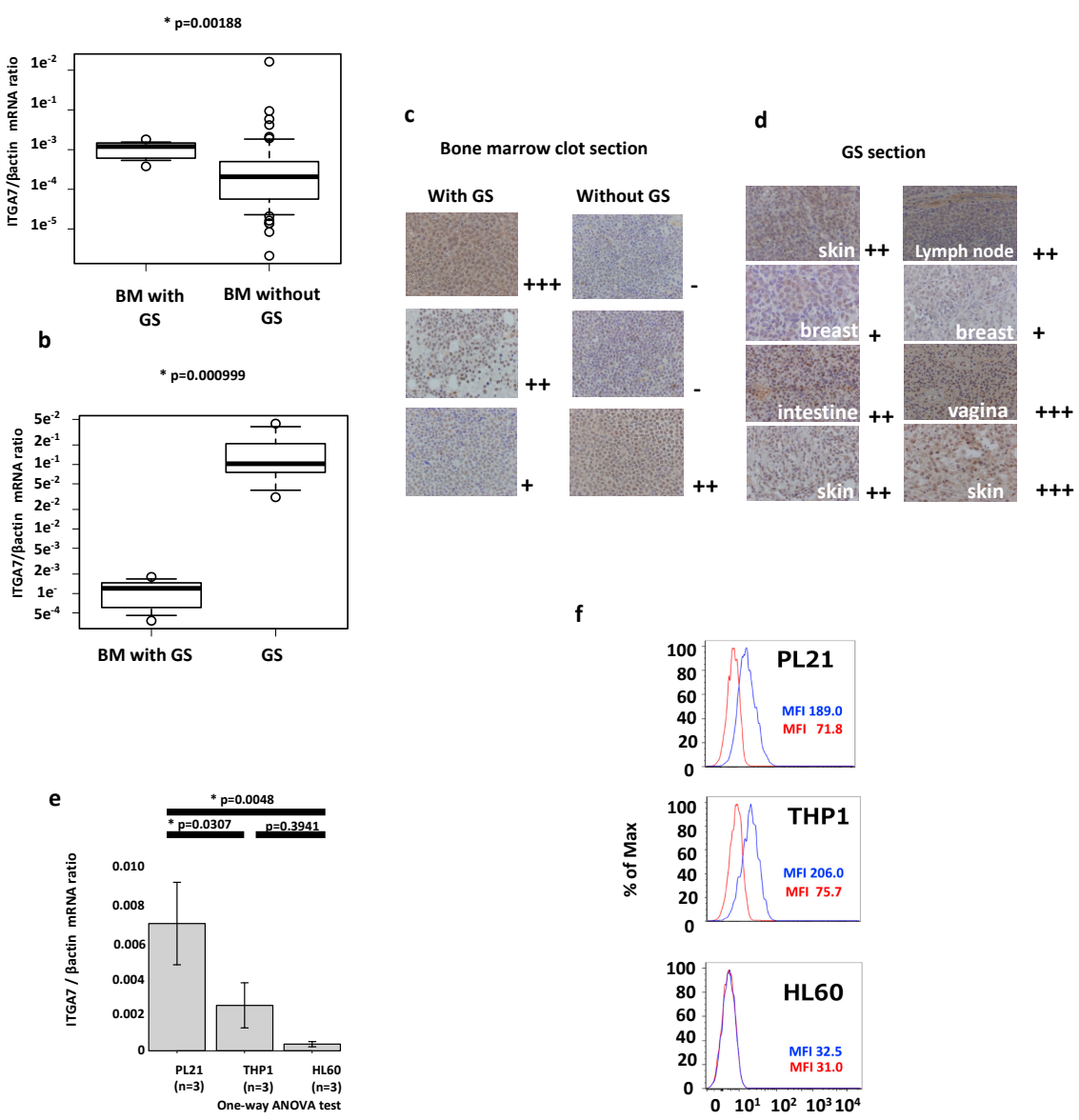

Figure 2. Validation of ITGA7/integrin $\alpha 7$ expression in patient samples and cell lines. (a) RT-qPCR-based expression of ITGA7 in AML with GS and AML without GS. The $y$ axis is logarithmic. (b) RT-qPCR-based expression of ITGA7 in GS formalin-fixed, paraffin-embedded (FFPE) sections. The circle plots mean each expression data. The square shows box plot. (c) Expression of integrin $\alpha 7$ in bone marrow clots and (d) FFPE sections of GS. Immunohistochemical staining was positive in the nuclei, cell membrane, and cytosol of atypical cells in the GS section or bone marrow clots with GS. Staining intensity is semiquantitative and is expressed as + to +++. (e) RT-qPCR expression of ITGA7 in AML cell lines. The vertical axis represents the ITGA7/ $\beta$-actin mRNA ratio. The error bars represent standard deviation of the mean. (f) Flow cytometric analysis of PL21 and THP1 cells expressing integrin $\alpha 7$ on their cell surface (blue line). An isotype control was used for the primary antibody (red line). The vertical axis represents cell percentage. The horizontal axis represents arbitrary units of mean fluorescence intensity.

In addition, ITGA7 expression in three AML cell lines was determined for functional studies. Among the five cell lines tested, PL21, which was established from AML accompanied by mediastinal GS, expressed the highest level of ITGA7, THP1 showed a moderate expression, and HL60 the lowest (Figure 2e). These findings are very similar to the RNA-Seq data obtained from Genentech via the Expression Atlas (https:/www.ebi.ac.uk/gxa/home) (Figure S4). In addition, the PL21 and THP1 cell lines expressed integrin $\alpha 7$ on the cell surface, whereas HL60, Kasumi-1, and KG-1 did not (Figure $2 \mathrm{f}$ and Figure S5).

\subsection{Laminin 211 Stimulates ERK Phosphorylation in AML Cell Lines Expressing Integrin $\alpha 7$}

We hypothesized that laminin stimulation, an integrin ligand, may enhance proliferation of AML cells via integrin $\alpha 7 \beta 1$. Based on previous reports regarding the affinity between laminin and integrin isoforms $[29,30]$, we assessed the phosphorylation of intracellular proteins in the presence of different 
laminin isoforms. To determine whether laminin 211 effectively transduces intracellular signals, ERK1/2 phosphorylation was detected in PL21 and THP1 cells upon stimulation with laminin 211. The results showed that laminin 211 stimulation for 15-60 min caused a gradual increase in the pERK1/ERK1 and pERK2/ERK2 ratios in both PL21 and THP1 cells, reaching a maximum of nearly twice the initial concentration at $60 \mathrm{~min}$ (Figure 3a,b). Alternatively, in HL60 cells, no laminin-211-mediated change was observed in the pERK1/ERK1 ratio; however, the pERK2/ERK2 ratio was 2.2-fold higher following 15 min of stimulation (Figure 3c). Further, laminin 411 stimulation also mildly increased the pERK1/ERK1 and pERK2/ERK2 ratios in PL21 cells and the pERK2/ERK2 ratio in HL60 cells but not in THP1 cells (Figure $3 \mathrm{a}-\mathrm{c}$ ).

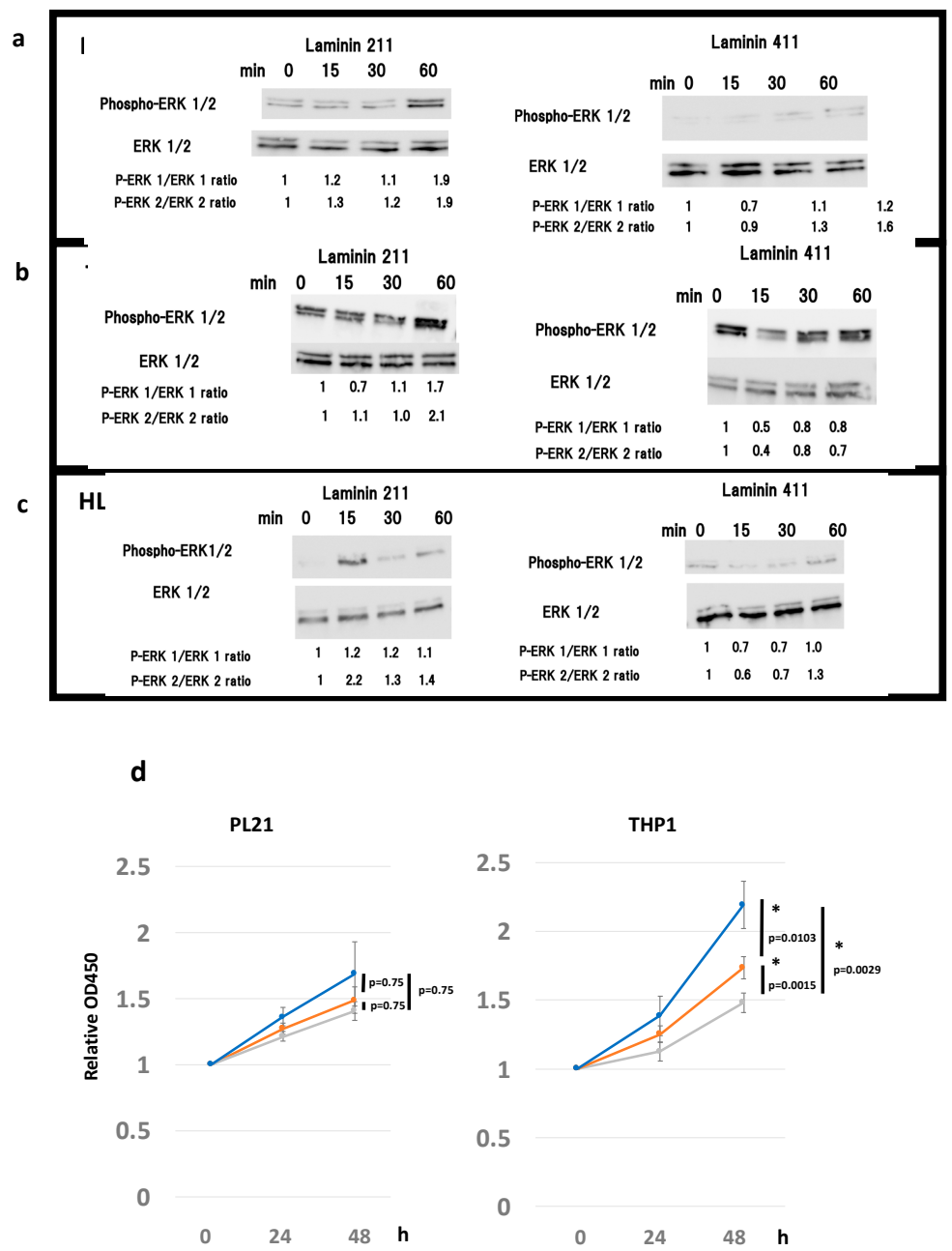

Figure 3. Effects of inhibitors on ERK1/2 and phospho-ERK1/2 protein expression and cellular proliferation indicate that laminin stimulates the integrin cascade. Western blot analysis of ERK1/2 and phospho-ERK1/2 after 15, 30, and 60 min of laminin 211, laminin 411, and control stimulation in (a) PL21, (b) THP1, and (c) HL60 cells. Numbers under the bands represent the relative band densities, as determined by densitometry, compared to the value at 0 min. (d) Proliferation of PL21 and THP1 cells in the presence of ERK inhibitor II (10 $\mu \mathrm{M}$ for PL21 and $100 \mu \mathrm{M}$ for THP1, gray line), Wortmannin (10 nM, orange line), or dimethyl sulfoxide (DMSO) (control, blue line). The error bars represent the standard error of the mean. ${ }^{*} p<0.05$ was considered statistically significant.

Based on these results, ERK inhibitor II or the Akt inhibitor Wortmannin were added to cells to determine if signaling through laminin 211 was involved in cell proliferation. Proliferation of PL21 cells was generally suppressed in the presence of these inhibitors, while that of THP1 cells was significantly suppressed (Figure 3d). 


\subsection{ECM Laminin 211 Promotes Proliferation of AML Cell Lines by Expressing Integrin $\alpha 7$}

Next, based on the phosphorylation assay results, we evaluated the difference in growth rate and morphological changes in culture dishes covered with various laminin isoforms.

Laminin 211 significantly increased the proliferation rate of PL21 cells compared with both laminin 411 and control during $72 \mathrm{~h}$ of culture (laminin 211 vs. laminin 411: $p=0.012$; laminin 211 vs. control: $p$ $=0.012$; Figure 4a). Similar results were obtained with the THP1 cell line, where laminin 211 increased the proliferation rate compared with both laminin 411 and control (laminin $211 \mathrm{vs.} \mathrm{laminin} \mathrm{411:} p=$ 0.023; laminin 211 vs. control: $p=0.012$; Figure 4b). In contrast, in HL60, Kasumi-1, and KG-1 cells, which do not express integrin $\alpha 7$, laminin 211 did not increase the proliferation rate (laminin $211 \mathrm{vs.}$ laminin 411: $p=0.16$; laminin 211 vs. control: $p=1.0$; Figure 4c and Figure S6). Laminin 411 did not affect the proliferation rate in any of these three cell lines when compared to the control, and no morphological changes were observed following stimulation with either laminin 211 or laminin 411 . Further, an adhesion study did not show adherence of AML cell lines to laminin (Figure S7), while cell cycle analysis via BrdU/7-AAD and flow cytometry demonstrated only a slight increase in the number of cells in S phase and G2/M phase (Figure S8).

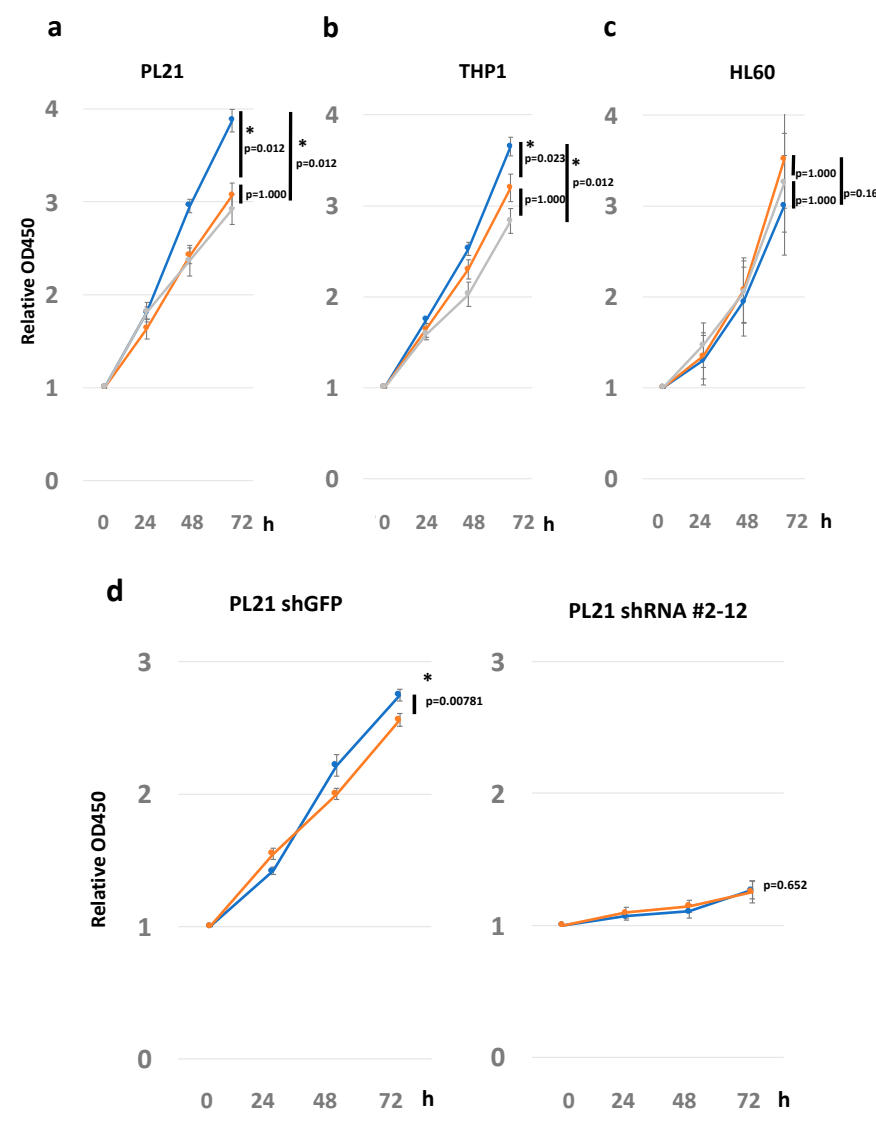

Figure 4. Cell proliferation assay with stimulation of laminin 211 and 411. Proliferation of (a) PL21, (b) THP1, and (c) HL60 cells in the presence of laminin 211, laminin 411, and the control groups. The vertical axis shows the proliferation rate starting at $0 \mathrm{~h}$. The horizontal axis shows various time points. The experiments were replicated three times. The lines indicate proliferation on dishes coated with laminin 211 (blue), laminin 411 (orange), or the uncoated control (gray). (d) Proliferation of PL21 with shGFP (control) and shITGA7 (\#2-12). Lines represent proliferation on dishes coated with laminin 211 (blue) or laminin 411 (orange). Proliferation rates for each of the conditions were analyzed by the Friedman test or Wilcoxon's rank sum test. The error bars show the standard error of the mean. ${ }^{*} p<$ 0.05 was considered statistically significant. 
To confirm the role of integrin $\alpha 7$ on cell proliferation, integrin $\alpha 7$ was knocked down by shRNA in PL21 cells. The results showed a diminished stimulatory effect by laminin, although it should be noted that cell growth was also suppressed by integrin $\alpha 7$ knockdown (Figure $4 \mathrm{~d}$ ).

To confirm that the interaction between laminin and integrin $\alpha 7$ stimulated ERK and Akt signaling, thus explaining their involvement in leukemic cell proliferation, the addition of ERK and Akt inhibitors was assessed. Both inhibitors induced a slight suppression in cell growth. Specifically, the ERK inhibitor abrogated growth promoted by laminin 211 in PL21 and THP1 cells (Figure 3d). Additionally, immunostaining confirmed the localization of the laminin $\alpha 1$ subunit, which constitutes the laminin 211 ligand, in tissues around GS (Figure S9).

\subsection{Clinical Implications of ITGA7 Expression in Bone Marrow AML Cells}

Next, the overall survival (OS) and relapse-free survival (RFS) of AML patients categorized by ITGA7 expression level were evaluated. Due to the small number of cases in this study, the cut-off value for ITGA7 expression was set using the quartile method. Clinical prognoses were analyzed in relation to ITGA7 expression as either below (low-expression group) or above (high-expression group) $25 \%$ of cases. Fifty-two patients who had received chemotherapy were included. Although the low-ITGA7-expression group (median not calculated) exhibited a more favorable median 5-year OS compared with the high-expression group (1.03 years) $(p=0.0047)$, no statistical difference was observed in the 3 -year RFS between the low (1.63 years) and high ( 0.99 years) ITGA7 groups ( $p=0.182$ ) (Figure 5A,B).

A

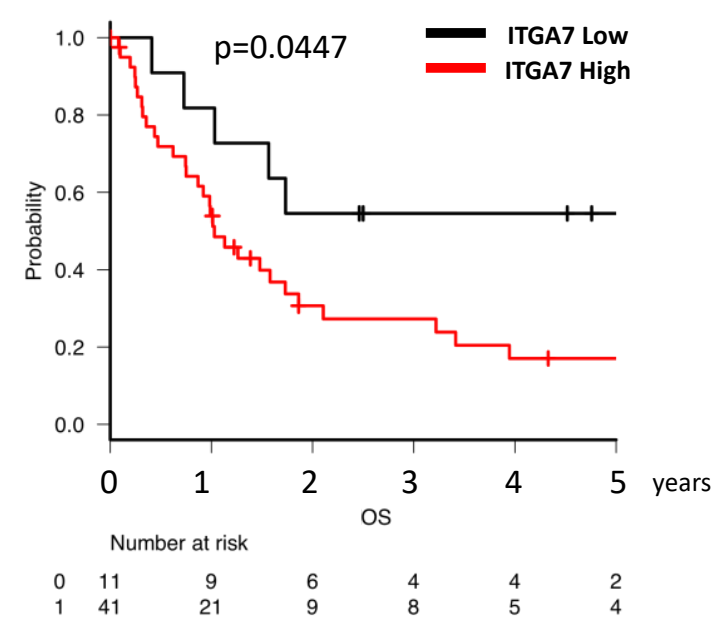

B

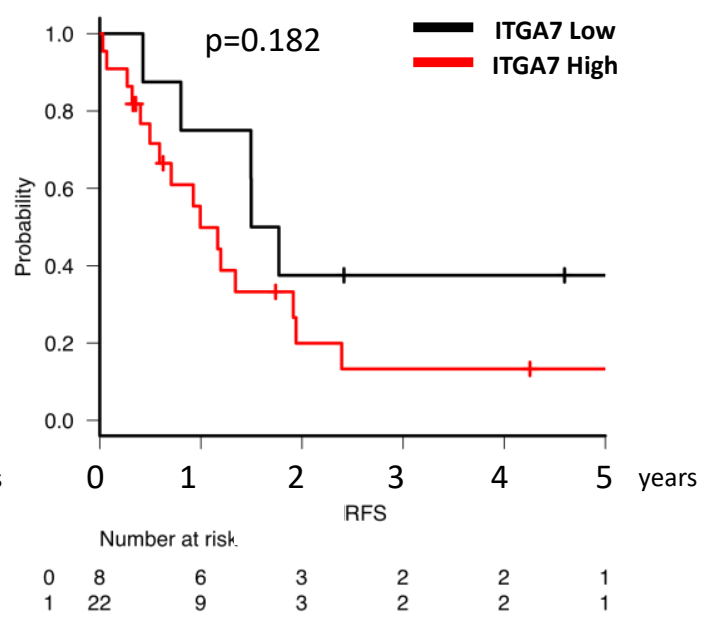

Figure 5. Clinical prognosis and ITGA7 expression in AML patients. (A) Overall survival (OS) of patients with high and low ITGA7 expression. (B) Relapse-free survival (RFS) of patients with high and low ITGA7 expression. A cut-off value based on the quartile method was applied: the low-expression group represents fewer than $25 \%$ of cases, and the high-expression group includes the remaining cases.

\section{Discussion}

In this study, we determined that the adhesion molecule integrin $\alpha 7$ was highly expressed in AML cells, especially in AML with GS. Its specific ligand, laminin 211, stimulates cell proliferation through the ERK signaling cascade, suggesting that the AML-ECM interaction is important for extramedullary disease formation.

Several factors and molecules associated with GS formation have previously been reported [31-34]. For example, type IV collagenase has been shown to facilitate the infiltration of the basement membrane and cause extramedullary invasion [7]. However, additional mechanisms and molecules are likely involved in GS formation. Comprehensive gene expression analysis via RNA-Seq is a widely accepted 
method for identifying novel candidate genes in an unbiased manner. GSEA based on our RNA-Seq data revealed that differential expression of cell surface molecules was key for GS generation. ITGA7, which encodes the adhesion molecule integrin $\alpha 7$, was selected since integrins have been described as playing an important role in cancer progression [35-37] as well as normal cell processes [38-40] through ECM binding [41,42] and transduction of cellular signaling [43-45]. Although the expression of ITGA7 in glioblastomas correlates to poor prognosis [35], the clinical significance of ITGA7 expression is controversial in other malignancies [35-37,46-51], and its role and expression in AML have not yet been characterized.

Our RT-qPCR results demonstrated significantly higher expression of ITGA7 in AML with GS in a large number of patient samples. The expression of the cell surface integrin $\alpha 7$ protein was also confirmed by immunohistochemistry of AML and GS samples. These data suggest a role for integrin $\alpha 7$ in GS formation. Although we also found that ITGA7 expression was markedly elevated in GS tissue, the RNA extracted from this tissue also included that of surrounding tissues which naturally express ITGA7; hence, the data showing elevated ITGA7 in GS samples must be interpreted carefully. Furthermore, a significant difference in ITGA7 distribution was noted in the non-GS-group tissues. One explanation for this may be that the high ITGA7 expression contributed to occult extramedullary AML infiltration without apparent GS formation, because in this study, we grouped AML with GS by histological proof or certification with CT imaging based on medical records. However, since we did not investigate factors regulating ITGA7 expression in this study, it is difficult to fully explain these results. Specifically, since platelet-derived growth factor (PDGF) is shown to upregulate both the mRNA and protein expression of ITGA7 in vascular smooth muscle cells [52], PDGF may have also contributed to integrin expression in the current study.

Integrin $\alpha 7$ forms a dimer with the ubiquitous integrin $\beta 1$ and activates intracellular signals using laminin as a ligand [53,54]. Integrin $\alpha 7 \beta 1$ is expressed in muscle and involved in the formation of muscle fibers through interaction with the ECM [38-40]. Laminin 211, a laminin isoform with a relatively high affinity for integrin $\alpha 7 \beta 1$, is expressed mainly in the skeletal and cardiac muscles, peripheral nerves, testes, thymus, and bone marrow [30,53-56]. It has also been reported that chronic inflammation stimulates growth of dormant cancer cells, linking the ECM to tumor development [57]. Thus, our data showing that proliferation of leukemic cells expressing integrin $\alpha 7$ is promoted by the ECM laminin 211 suggests that the growth advantage experienced in extramedullary microenvironments, such as muscles with abundant ECM, favors the generation of GS.

ERK phosphorylation following binding of laminin 211 to integrin $\alpha 7$ supports the idea that ECM-integrin interaction can stimulate an intracellular signal cascade in leukemic cells. ERK signal transduction plays an important role in leukemic cell proliferation and is often implicated in sensitivity and resistance to leukemia therapy [58]. Integrin $\alpha 7$ knockdown also significantly affected cell growth, confirming similar previous observations in glioblastoma cells [35] and reinforcing the importance of this integrin in AML cells. Further, AML has been correlated with increased expression of ECM-related genes and the degradation of surrounding ECM following release of matrix metalloproteinases [21,59]. Hence, AML cells appear to actively exploit the ECM to favor their growth and maintenance. The ECM-integrin interaction identified here may stimulate other signaling pathways with roles beyond cell proliferation, which will require further examination.

Finally, survival data demonstrated that low ITGA7 expression was associated with improved OS, as the expression of ITGA7 provides an advantage to GS when growing in the extramedullary site, thereby favoring its development. Additionally, ITGA7 expression in bone marrow leukemic cells may impact survival through this advantage afforded to GS. However, in our previous and present studies, GS demonstrated clinical significance only in terms of RFS and not OS, suggesting an alternate role for integrin $\alpha 7$ in AML compared with its role in GS formation. We did not quantify integrin $\alpha 7$ protein in all AML patients in this study, and the clinical utility of doing so should be pursued in the future. 


\section{Materials and Methods}

\subsection{Patient Samples}

A total 64 AML patients (9 with GS and 55 without) participated in this study. Prior to the collection of patient samples, approval was obtained from the Institutional Review Board of Gunma University Hospital (IRB code: \#1295). Informed consent about use of clinical samples was obtained from all patients. Bone marrow aspiration was performed at the time of AML diagnosis. Mononuclear cells from the bone marrow of the patients were separated with a gradient medium and the cell pellet was resuspended in RPMI 1640 containing dimethyl sulfoxide (DMSO) as cell stock medium and stored at $-80{ }^{\circ} \mathrm{C}$.

\subsection{Cell Culture}

The AML cell lines used in the experiments were PL21, THP1, HL60, Kasumi-1, and KG-1. HL60 (\#CCL240) was purchased from the American Type Culture Collection (ATCC, Manassas, VA, USA). PL21 (\#JCRB1319), THP1 (\#RCB1189), KG-1 (\#JCRB0065), and Kasumi-1 (\#JCRB1003) were from the Riken Cell Bank (Tsukuba, Japan). PL21 was derived from an AML M3 patient without t (15;17) with myeloid sarcoma at a mediastinal site. The THP1 cell line was derived from an AML M5 patient, whereas HL60 was from an AML M2 patient [60]. All cell lines were maintained in RPMI 1640 medium with $10 \%$ fetal bovine serum (FBS), 100 units/mL of penicillin, $100 \mu \mathrm{g} / \mathrm{mL}$ of streptomycin, and $0.25 \mu \mathrm{g} / \mathrm{mL} \mathrm{of}$ amphotericin (\#15240062; Thermo Fisher Scientific, Waltham, MA, USA) at $37^{\circ} \mathrm{C}$ and $5 \% \mathrm{CO}_{2}$.

\subsection{Lentiviral Constructs and ITGA7 Knockdown}

ITGA7 knockdown was performed with a lentiviral transduction using a shRNA sequence. Lentivirus preparation was performed as previously described [61]. The ITGA7 target sequence [35] was as follows: Forward, $5^{\prime}$-CCGGCCTCCGGGATTTGCTACCTTTCTCGAGAAAGGTAGCAAATCCCGG AGGTTTTT-3' ; Reverse, 5' -AATTAAAAACCTCCGGGATTTGCTACCTTTCTCGAGAAAGGTAGCAA ATCCCGGAGG-3'.

\subsection{Cell Proliferation Assay}

Human recombinant laminin (\#BLA-LN211-02, \#BLA-LN411-02; Biolamina, Sundbyberg, Sweden) was diluted to $10 \mu \mathrm{g} / \mathrm{mL}$ with Dulbecco's phosphate-buffered saline (\#14040141; Invitrogen, Carlsbad, CA, USA) according to the manufacturer's protocol. Next, $70 \mu \mathrm{L}$ of the diluted laminin was added to each well of a 96-well plate (\#353872; Corning Inc., Corning, NY, USA) and stored at $4{ }^{\circ} \mathrm{C}$ overnight for coating. PL21, THP1, and HL60 cell numbers were adjusted to $1.5 \times 10^{5}$ cells/mL with RPMI 1640 medium, and $100 \mu \mathrm{L}\left(1.5 \times 10^{4}\right.$ cells/well $)$ was transferred to each well after removal of the supernatant containing laminin. The cells were cultured at $37^{\circ} \mathrm{C}$ and $5 \% \mathrm{CO}_{2}$. For counting, $10 \mu \mathrm{L}$ of the Cell Counting Kit-8 (\#343-07623; Dojindo, Kumamoto, Japan) reagent was added to each well at various time points $(0,24,48$, and $72 \mathrm{~h})$ and incubated at $37^{\circ} \mathrm{C}$ with $5 \% \mathrm{CO}_{2}$ for $2 \mathrm{~h}$. After that, absorbance at $450 \mathrm{~nm}$ was measured using a Wallac ARVO-SX 1420 spectrophotometer (PerkinElmer, Waltham, MA, USA). The proliferation rate of cell lines was calculated by dividing the absorbance at $450 \mathrm{~nm}$ for each time point by the absorbance at $0 \mathrm{~h}$.

Proliferation assays were also performed in the presence of ERK inhibitor II (\#sc-203945; Santa Cruz Biotechnology, Dallas, TX, USA) and Wortmannin (\#AG-CN2-0023-M001; AdipoGen Corporation, San Diego, CA, USA) diluted in DMSO. The final concentration of ERK inhibitor II was $10 \mu \mathrm{M}$ (PL21) or $100 \mu \mathrm{M}$ (THP1), whereas that of Wortmannin was $100 \mathrm{nM}$ for both cell lines. DMSO's final concentration was $1 \%$ in all cases. All experiments were performed in technical and biological triplicates.

\subsection{RNA Extraction and RNA-Seq}

Total RNA was extracted from bone marrow mononuclear cells using the RNeasy kit (\#74104; QIAGEN, Hilden, Germany), or FFPE bone marrow clots from an AML M1 patient with GS or FFPE GS 
sections using the NucleoSpin total RNA FFPE XS kit (\#U0969A; TaKaRa Bio, Shiga, Japan) following the manufacturer's protocols. RNA purity and concentration were measured using a spectrophotometer (\#B-80-3004-31; Implen GmbH, München, Germany). RNA integrity numbers were confirmed to be higher than seven using the Agilent RNA6000 Pico kit (\#5067-1513) in an Agilent 2100 Bioanalyzer (Agilent, Santa Clara, CA, USA). RNA-Seq was performed on seven AML specimens with GS and seven without GS. To construct the RNA library, the NEBNext Ultra RNA Library Prep Kit for Illumina (\#E7530S; NEB, Ipswich, MA, USA), NEBNext rRNA Depletion Kit (\#E6310L), Agencourt AMPure XP (\#A63881; Beckman Coulter, Brea, CA, USA), and Agencourt RNAClean XP (\#A63987) were used following the respective manufacturer's protocols. The quality and concentration of the amplified complementary DNA (cDNA) library were determined using the Agilent 2100 Bioanalyzer with the high-sensitivity DNA kit (\#5067-4626; Agilent) and the EnSpire plate reader (\#11310334; PerkinElmer). RNA-Seq was performed on a NextSeq 500 (Illumina, San Diego, CA, USA) with NextSeq 500/550 high-output kit v2 (\#FC-404-2005; NEB). Raw data were aligned against the human genome reference (hg19) using TopHat version 2.0. Gene expression levels were quantified using Cufflinks \& DE version 2.0. GSEA (Broad Institute, Cambridge, MA, USA) [62,63] was performed to determine the enrichment of specific gene sets in the RNA-Seq data. The RNA-Seq data were submitted to the DDBJ/EMBL/GenBank databases under accession number DRA009575.

\section{6. $R T-q P C R$}

Total RNA was first converted to cDNA with the high-capacity RNA to cDNA kit (\#4387406; Applied Biosystems, Foster City, CA, USA) and then used for RT-qPCR to evaluate the relative expression of the ITGA7 gene. The RT-qPCR reaction was measured on a 7300 Real-Time PCR System (Applied Biosystems) using the Power SYBR ${ }^{\circledR}$ Green PCR Master Mix (\#4367659; Applied Biosystems). Primer (TaKaRa Bio) sequences were as follows:

ITGA7: Forward, 5'-GCTGCCCACTCTACAGCTTTGAC-3'; Reverse, 5'-ACAATCACTTCCAG GGACTTCACA-3';

$\beta$-actin: Forward, 5'-TGGCACCCAGCACAATGAA-3'; Reverse, 5'-CTAAGTCATAGTCCGCC

TAGAAGCA- $3^{\prime}$. The relative levels of ITGA7 mRNA were evaluated by the $2^{-\Delta \Delta \mathrm{Ct}}$ method by normalizing expression to the $\beta$-actin gene.

\subsection{Flow Cytometric Analysis}

Flow cytometric analysis was conducted using anti-human ITGA7 antibodies (\#ab195959; Abcam, Cambridge, UK). The cells were washed twice with cold phosphate-buffered saline (PBS) and incubated in PBS containing 2\% FBS with either primary antibody or isotype, followed by fluorescein isothiocyanate (FITC)-conjugated secondary antibody. Samples were then analyzed on a BD FACS Canto II (Becton Dickinson, Franklin Lakes, NJ, USA), and data were analyzed using FlowJo software version 9.7.7 (FlowJo, Ashland, OR, USA).

\subsection{Western Blot Analysis}

Whole cell lysates were obtained using RIPA lysis buffer containing phenylmethylsulfonyl fluoride, protease inhibitor cocktail, and sodium orthovanadate (\#sc-24948; Santa Cruz Biotechnology). Harvested cells were lysed in RIPA lysis buffer. Then, they were frozen and thawed twice and centrifuged at 15,000 rpm for $10 \mathrm{~min}$. The supernatant was collected as whole cell lysate. The samples were suspended 1:1 in sample buffer and Laemmli 2× concentrate (\#S3401-10VL; Sigma-Aldrich, St. Louis, MO, USA), and $5 \mu \mathrm{g}$ of total protein per well was loaded onto an SDS-PAGE gel (4-20\% gradient gel, \#4561095; Bio-Rad, Hercules, CA, USA). After resolving, the bands were transferred onto a polyvinylidene difluoride membrane (\#IPVH00010; Merck Millipore Ltd., Billerica, MA, USA) for $1 \mathrm{~h}$ at $17 \mathrm{~V}$ and then blocked in Tris-buffered saline $-0.5 \%$ Tween 20 (TBS-T) with $0.3 \%$ dry, nonfat milk for $30 \mathrm{~min}$ at room temperature. The blocked membrane was incubated with the primary antibody (1:1000, Erk1/2 monoclonal antibody, phosphor-ERK1/2 monoclonal antibody from the \#12651 PDGF Receptor 
Activation Antibody Sampler Kit; Cell Signaling Technology, Danvers, MA, USA) at $4{ }^{\circ} \mathrm{C}$ overnight. After washing three times with TBS-T, the membrane was incubated for $1 \mathrm{~h}$ at room temperature with horseradish-peroxidase-conjugated secondary antibody (1:3000, \#7074S, Cell Signaling Technology) and strep-tactin (1:10,000,\#161-0381; Bio-Rad). Antibody-labeled proteins were detected by enhanced chemiluminescence with Signal Fire (\#6883P3; Cell Signaling Technology) using the Image Quant LAS 4010 system (GE Healthcare, Chicago, IL, USA). Band intensities were measured with ImageJ software version. 1.51s.

\subsection{Immunohistochemical Staining}

Immunohistochemical staining was performed using $3^{\prime}, 3^{\prime}$-diaminobenzidine (DAB) according to the peroxidase complex method. Paraffin sections were dehydrated at $44{ }^{\circ} \mathrm{C}$ for $60 \mathrm{~min}$ and deparaffinized. The antigen was activated with citrate buffer at pH 9.0 (\#415201; Nichirei, Tokyo, Japan) and blocked using 10\% horse serum (\#16050; Gibco, Gaithersburg, MD, USA) and 1\% sodium azide. Sections were incubated with polyclonal rabbit anti-human ITGA7 (1:400, \#HPA008427; Abcam) at $4^{\circ} \mathrm{C}$ overnight. The samples were then washed and stained using Histofine simple stain MAX PO (Nichirei) as the secondary antibody. Color development was acquired with DAB (\#347-00904; Dojindo).

\subsection{Statistical Analysis}

All data were analyzed using EZR version 1.33 [64]. The RT-qPCR data were divided into control and test groups and analyzed by Student's $t$ test or the Mann-Whitney $U$ test. For cell proliferation experiments, the growth rate at each time point was analyzed using the Friedman test. For OS and RFS calculations, cut-off values were determined by the quartile method and the relationship between ITGA7 expression and presence of GS was derived. The log-rank test was applied for OS; RFS was determined by the clinical course. Differences were considered significant at $p<0.05$. False discovery rates were generated using Cufflinks and GSEA for RNA-Seq data.

\section{Conclusions}

In conclusion, our data revealed that leukemic cells express the ITGA7-encoded integrin $\alpha 7$ in association with GS. The ECM laminin 211 functions as a ligand of ITGA7 to stimulate ERK signaling and cell proliferation. This is the first study to demonstrate the interaction between integrin $\alpha 7$ and the ECM in leukemic cells. Further studies are needed to clarify the precise role of integrin $\alpha 7$ in leukemic cells and to develop novel therapeutic strategies targeting this molecule.

Supplementary Materials: The following are available online at http://www.mdpi.com/2072-6694/12/2/363/s1, Figure S1: RNA-Seq data for ITGA7 obtained from The Cancer Genome Atlas (TCGA), Figure S2: RNA-Seq data from this experiment, Figure S3: Flow cytometric analysis of bone marrow specimens, Figure S4: RNA-Seq data of human cell lines from Genentech via the Expression Atlas, Figure S5: Flow cytometric analysis of AML cell lines, Figure S6: Proliferation of AML cell lines with laminin isoforms, Figure S7: Adhesion assay, Figure S8: Cell cycle assay with BrdU and 7-AAD, Figure S9: Immunohistochemical staining for laminin $\alpha 1$ subunit, Table S1: Background of the patients participating in the RNA-Seq analysis.

Author Contributions: Conceptualization, H.H.; Data curation, N.K. and H.H.; Formal analysis, N.K. and H.H.; Investigation, N.K., T.O., K.H., K.K.-M., Y.K., R.I., and Y.M.; Methodology, H.H.; Project administration, H.H.; Supervision, H.H.; Validation, N.K.; Visualization and N.K.; Writing-original draft, N.K.; Writing-review and editing, N.K., M.T., T.O., T.I., N.T., A.Y., H.T., T.S., H.S., H.M., and H.H. All authors have read and agreed to the published version of the manuscript.

Funding: This research received no external funding.

Acknowledgments: The authors wish to acknowledge Rumiko Koitabashi, Gunma University Graduate School of Medicine, for technical support during immunohistochemistry. The authors would also like to thank Editage (http://www.editage.jp) for English language editing.

Conflicts of Interest: The authors declare no conflict of interest. 


\section{References}

1. Döhner, H.; Weisdorf, D.J.; Bloomfield, C.D. Acute myeloid leukemia. N. Engl. J. Med. 2015, 373, 1136-1152. [CrossRef] [PubMed]

2. Dohner, H.; Estey, E.; Grimwade, D.; Amadori, S.; Appelbaum, F.R.; Ebert, B.L.; Fenaux, P.; Larson, R.A.; Levine, R.L.; Lo-coco, F.; et al. Diagnosis and management of AML in adults: 2017 ELN recommendations from an international expert panel hartmut. Blood 2017, 129, 424-448. [CrossRef] [PubMed]

3. Arber, D.A.; Orazi, A.; Hasserjian, R.; Borowitz, M.J.; Le Beau, M.M.; Bloomfield, C.D.; Cazzola, M.; Vardiman, J.W. The 2016 revision to the World Health Organization classification of myeloid neoplasms and acute leukemia. Blood 2016, 127, 2391-2406. [CrossRef] [PubMed]

4. Dombret, H.; Gardin, C. An update of current treatments for adult acute myeloid leukemia. Blood 2016, 127, 53-61. [CrossRef] [PubMed]

5. Shimizu, H.; Saitoh, T.; Hatsumi, N.; Takada, S.; Yokohama, A.; Handa, H.; Jimbo, T.; Sakura, T.; Tsukamoto, N.; Murakami, H.; et al. Clinical significance of granulocytic sarcoma in adult patients with acute myeloid leukemia. Cancer Sci. 2012, 103, 1513-1517. [CrossRef] [PubMed]

6. Shimizu, H.; Saitoh, T.; Machida, S.; Kako, S.; Doki, N.; Mori, T.; Sakura, T.; Kanda, Y.; Kanamori, H.; Miyawaki, S.; et al. Allogeneic hematopoietic stem cell transplantation for adult patients with mixed phenotype acute leukemia: Results of a matched-pair analysis. Eur. J. Haematol. 2015, 95, 455-460. [CrossRef]

7. Kobayashi, M.; Hamada, J.; Li, Y.-Q.; Shinobu, N.; Imamura, M.; Okada, F.; Takeuchi, N.; Hosokawa, M. A possible role of $92 \mathrm{kDa}$ type IV collagenase in the extramedullary tumor formation in leukemia. Jpn. J. Cancer Res. 1995, 86, 298-303. [CrossRef]

8. Bianconi, D.; Unseld, M.; Prager, G.W. Integrins in the spotlight of cancer. Int. J. Mol. Sci. 2016, $17,2037$. [CrossRef]

9. Sangaletti, S.; Chiodoni, C.; Tripodo, C.; Colombo, M.P. Common extracellular matrix regulation of myeloid cell activity in the bone marrow and tumor microenvironments. Cancer Immunol. Immunother. 2017, 66, 1059-1067. [CrossRef]

10. Pickup, M.W.; Mouw, J.K.; Weaver, V.M. The extracellular matrix modulates the hallmarks of cancer. EMBO Rep. 2014, 15, 1243-1253. [CrossRef]

11. Lu, P.; Weaver, V.M.; Werb, Z. The extracellular matrix: A dynamic niche in cancer progression. J. Cell Biol. 2012, 196, 395-406. [CrossRef] [PubMed]

12. Levental, K.R.; Yu, H.; Kass, L.; Lakins, J.N.; Egeblad, M.; Erler, J.T.; Fong, S.F.T.; Csiszar, K.; Giaccia, A.; Weninger, W.; et al. Matrix crosslinking forces tumor progression by enhancing integrin signaling. Cell 2009, 139, 891-906. [CrossRef] [PubMed]

13. Xiong, J.; Balcioglu, H.E.; Danen, E.H.J. Integrin signaling in control of tumor growth and progression. Int. J. Biochem. Cell Biol. 2013, 45, 1012-1015. [CrossRef] [PubMed]

14. Ata, R.; Antonescu, C.N. Integrins and cell metabolism: An intimate relationship impacting cancer. Int. J. Mol. Sci. 2017, 18, 189. [CrossRef] [PubMed]

15. Maziveyi, M.; Alahari, S.K.; Maziveyi, M.; Alahari, S.K. Cell matrix adhesions in cancer: The proteins that form the glue. Oncotarget 2015, 8, 48471-48487. [CrossRef] [PubMed]

16. Giancotti, F.G.; Ruoslahti, E. Integrin signaling. Science 1999, 285, 1028-1032. [CrossRef]

17. Matsunaga, T.; Takemoto, N.; Sato, T.; Takimoto, R.; Tanaka, I.; Fujimi, A.; Akiyama, T.; Kuroda, H.; Kawano, Y.; Kobune, M.; et al. Interaction between leukemic-cell VLA-4 and stromal fibronectin is a decisive factor for minimal residual disease of acute myelogenous leukemia. Nat. Med. 2003, 9, 1158-1165. [CrossRef]

18. Becker, P.S.; Kopecky, K.J.; Wilks, A.N.; Chien, S.; Harlan, J.M.; Willman, C.L.; Petersdorf, S.H.; Stirewalt, D.L.; Papayannopoulou, T.; Appelbaum, F.R. Very late antigen-4 function of myeloblasts correlates with improved overall survival for patients with acute myeloid leukemia. Blood 2009, 113, 866-874. [CrossRef]

19. Walter, R.B.; Alonzo, T.A.; Gerbing, R.B.; Ho, P.A.; Smith, F.O.; Raimondi, S.C.; Hirsch, B.A.; Gamis, A.S.; Franklin, J.L.; Hurwitz, C.A.; et al. High expression of the very late antigen-4 integrin independently predicts reduced risk of relapse and improved outcome in pediatric acute myeloid leukemia: A report from the children's oncology group. J. Clin. Oncol. 2010, 28, 2831-2838. [CrossRef]

20. Tavernier-Tardy, E.; Cornillon, J.; Campos, L.; Flandrin, P.; Duval, A.; Nadal, N.; Guyotat, D. Prognostic value of CXCR4 and FAK expression in acute myelogenous leukemia. Leuk. Res. 2009, 33, 764-768. [CrossRef] 
21. Izzi, V.; Lakkala, J.; Devarajan, R.; Ruotsalainen, H.; Savolainen, E.; Koistinen, P.; Heljasvaara, R.; Pihlajaniemi, T. An extracellular matrix signature in leukemia precursor cells and acute myeloid leukemia. Haematologica 2017, 102, e245-e248. [CrossRef] [PubMed]

22. Shah, C.A.; Bei, L.; Wang, H.; Altman, J.K.; Platanias, L.C.; Eklund, E.A. Cooperation between AlphavBeta3 integrin and the fibroblast growth factor receptor enhances proliferation of Hoxoverexpressing acute myeloid leukemia cells. Oncotarget 2016, 7, 54782-54794. [CrossRef] [PubMed]

23. Johansen, S.; Brenner, A.K.; Bartaula-Brevik, S.; Reikvam, H.; Bruserud, Ø. The possible importance of $\beta 3$ integrins for leukemogenesis and chemoresistance in acute myeloid leukemia. Int. J. Mol. Sci. 2018, $19,251$. [CrossRef] [PubMed]

24. Reinisch, A.; Majeti, R. Sticking it to the niche: CD98 mediates critical adhesive signals in AML. Cancer Cell 2016, 30, 662-664. [CrossRef] [PubMed]

25. Bajaj, J.; Konuma, T.; Lytle, N.K.; Kwon, H.Y.; Ablack, J.N.; Cantor, J.M.; Rizzieri, D.; Chuah, C.; Oehler, V.G.; Broome, E.H.; et al. CD98-mediated adhesive signaling enables the establishment and propagation of acute myelogenous leukemia. Cancer Cell 2016, 30, 792-805. [CrossRef] [PubMed]

26. Miller, P.G.; Al-Shahrour, F.; Hartwell, K.A.; Chu, L.P.; Järås, M.; Puram, R.V.; Puissant, A.; Callahan, K.P.; Ashton, J.; McConkey, M.E.; et al. Invivo rnai screening identifies a leukemia-specific dependence on integrin beta 3 signaling. Cancer Cell 2013, 24, 45-58. [CrossRef]

27. Jin, L.; Hope, K.J.; Zhai, Q.; Smadja-Joffe, F.; Dick, J.E. Targeting of CD44 eradicates human acute myeloid leukemic stem cells. Nat. Med. 2006, 12, 1167-1174. [CrossRef]

28. Liberzon, A.; Birger, C.; Thorvaldsdóttir, H.; Ghandi, M.; Mesirov, J.P.; Tamayo, P. The molecular signatures database hallmark gene set collection. Cell Syst. 2015, 1, 417-425. [CrossRef]

29. Ramovs, V.; te Molder, L.; Sonnenberg, A. The opposing roles of laminin-binding integrins in cancer. Matrix Biol. 2017, 57, 213-243. [CrossRef]

30. Barczyk, M.; Carracedo, S.; Gullberg, D. Integrins. Cell Tissue Res. 2010, 339, 269-280. [CrossRef]

31. Wilson, C.S.; Medeiros, L.J. Extramedullary manifestations of myeloid neoplasms. Am. J. Clin. Pathol. 2015, 144, 219-239. [CrossRef]

32. Pileri, S.A.; Ascani, S.; Cox, M.C.; Campidelli, C.; Bacci, F.; Piccioli, M.; Piccaluga, P.P.; Agostinelli, C.; Asioli, S.; Novero, D.; et al. Myeloid sarcoma: Clinico-pathologic, phenotypic and cytogenetic analysis of 92 adult patients. Leukemia 2007, 21, 340-350. [CrossRef] [PubMed]

33. Zhang, X.H.; Zhang, R.; Li, Y. Granulocytic sarcoma of abdomen in acute myeloid leukemia patient with $\operatorname{inv}(16)$ and $\mathrm{t}(6 ; 17)$ abnormal chromosome: Case report and review of literature. Leuk. Res. 2010, 34, 958-961. [CrossRef] [PubMed]

34. Chang, H.; Brandwein, J.; Yi, Q.L.; Chun, K.; Patterson, B.; Brien, B. Extramedullary infiltrates of AML are associated with CD56 expression, 11q23 abnormalities and inferior clinical outcome. Leuk. Res. 2004, 28, 1007-1011. [CrossRef]

35. Haas, T.L.; Sciuto, M.R.; Brunetto, L.; Valvo, C.; Signore, M.; Fiori, M.E.; di Martino, S.; Giannetti, S.; Morgante, L.; Boe, A.; et al. Integrin $\alpha 7$ is a functional marker and potential therapeutic target in glioblastoma. Cell Stem Cell 2017, 21, 35-50. [CrossRef]

36. Shi, W.D.; Meng, Z.Q.; Chen, Z.; Lin, J.H.; Zhou, Z.H.; Liu, L.M. Identification of liver metastasis-related genes in a novel human pancreatic carcinoma cell model by microarray analysis. Cancer Lett. 2009, 283, 84-91. [CrossRef] [PubMed]

37. Hamidi, H.; Ivaska, J. Every step of the way: Integrins in cancer progression and metastasis. Nat. Rev. Cancer 2018, 18, 1-16. [CrossRef] [PubMed]

38. Xiao, J.; Jethanandani, P.; Ziober, B.L.; Kramer, R.H. Regulation of alpha7 integrin expression during muscle differentiation. J. Biol. Chem. 2003, 278, 49780-49788. [CrossRef] [PubMed]

39. Heller, K.N.; Montgomery, C.L.; Janssen, P.M.; Clark, K.R.; Mendell, J.R.; Rodino-Klapac, L.R. AAV-mediated overexpression of human $\alpha 7$ integrin leads to histological and functional improvement in dystrophic mice. Mol. Ther. 2013, 21, 520-525. [CrossRef]

40. Siegel, A.L.; Atchison, K.; Fisher, K.E.; Davis, G.E.; Cornelison, D.D.W. 3D timelapse analysis of muscle satellite cell motility. Stem Cells 2009, 27, 2527-2538. [CrossRef]

41. Vizirianakis, I.S.; Yao, C.C.; Chen, Y.Q.; Ziober, B.L.; Tsiftsoglou, A.S.; Kramer, R.H. Transfection of MCF-7 carcinoma cells with human integrin $\alpha 7$ cDNA promotes adhesion to laminin. Arch. Biochem. Biophys. 2001, 385, 108-116. [CrossRef] 
42. Chöber, S.; Mielenz, D.; Echtermeyer, F.; Hapke, S.; Pöschl, E.; Von der Mark, H.; Moch, H.; Von der Mark, K. The role of extracellular and cytoplasmic splice domains of $\alpha 7$-integrin in cell adhesion and migration on laminins. Exp. Cell Res. 2000, 255, 303-313. [CrossRef] [PubMed]

43. Boppart, M.D.; Burkin, D.J.; Kaufman, S.J. Activation of AKT signaling promotes cell growth and survival in $\alpha 7 \beta 1$ integrin-mediated alleviation of muscular dystrophy. Biochim. Biophys. Acta-Mol. Basis Dis. 2011, 1812, 439-446. [CrossRef] [PubMed]

44. Kikkawa, Y.; Yu, H.; Genersch, E.; Sanzen, N.; Sekiguchi, K.; Fässler, R.; Campbell, K.P.; Talts, J.F.; Ekblom, P. Laminin isoforms differentially regulate adhesion, spreading, proliferation, and ERK activation of $\beta 1$ integrin-null cells. Exp. Cell Res. 2004, 300, 94-108. [CrossRef] [PubMed]

45. Mielenz, D.; Hapke, S.; Pöschl, E.; Von der Mark, H.; Von der Mark, K. The integrin $\alpha 7$ cytoplasmic domain regulates cell migration, lamellipodia formation, and p130CAS/Crk coupling. J. Biol. Chem. 2001, 276, 13417-13426. [CrossRef] [PubMed]

46. Bhandari, A.; Xia, E.; Zhou, Y.; Guan, Y.; Xiang, J.; Kong, L.; Wang, Y.; Yang, F.; Wang, O.; Zhang, X. ITGA7 functions as a tumor suppressor and regulates migration and invasion in breast cancer. Cancer Manag. Res. 2018, 10, 969-976. [CrossRef]

47. Liu, J.; Zhang, Z.; Li, X.; Chen, J.; Wang, G.; Tian, Z.; Qian, M.; Chen, Z.; Guo, H.; Tang, G.; et al. Forkhead box $\mathrm{C} 1$ promotes colorectal cancer metastasis through transactivating ITGA7 and FGFR4 expression. Oncogene 2018, 37, 1-15. [CrossRef]

48. Li, X.; Wang, J.; Zhang, C.; Lin, C.; Zhang, J.; Zhang, W.; Zhang, W.; Lu, Y.; Zheng, L.; Li, X. Circular RNA circITGA7 inhibits colorectal cancer growth and metastasis by modulating the Ras pathway and upregulating transcription of its host gene. ITGA7 J. Pathol. 2018, 246, 166-179. [CrossRef]

49. Burkin, D.J.; Fontelonga, T.M. Mesothelioma cells breaking bad: Loss of integrin $\alpha 7$ promotes cell motility and poor clinical outcomes in patients. J. Pathol. 2015, 237, 282-284. [CrossRef]

50. Tan, L.Z.; Song, Y.; Nelson, J.; Yu, Y.P.; Luo, J.H. Integrin $\alpha 7$ binds tissue inhibitor of metalloproteinase 3 to suppress growth of prostate cancer cells. Am. J. Pathol. 2013, 183, 831-840. [CrossRef]

51. Ziober, B.L.; Chen, Y.Q.; Ramos, D.M.; Waleh, N.; Kramer, R.H. Expression of the alpha7beta1 laminin receptor suppresses melanoma growth and metastatic potential. Cell Growth Differ. 1999, 10, 479-490.

52. Chao, J.T.; Martinez-Lemus, L.A.; Kaufman, S.J.; Meininger, G.A.; Ramos, K.S.; Wilson, E. Modulation of $\alpha 7$-integrin-mediated adhesion and expression by platelet-derived growth factor in vascular smooth muscle cells. Am. J. Physiol.-Cell Physiol. 2006, 290, C972-C980. [CrossRef] [PubMed]

53. Campbell, I.D.; Humphries, M.J. Integrin structure, activation, and interactions. Cold Spring Harb. Perspect. Biol. 2011, 3, a004994. [CrossRef] [PubMed]

54. Durbeej, M. Laminins. Cell Tissue Res. 2010, 339, 259-268. [CrossRef] [PubMed]

55. Siler, U.; Seiffert, M.; Puch, S.; Richards, A.; Torok-Storb, B.; Müller, C.A.; Sorokin, L.; Klein, G. Characterization and functional analysis of laminin isoforms in human bone marrow. Blood 2000, 96, 4194-4203. [CrossRef] [PubMed]

56. Patarroyoa, M.; Tryggvasonb, K.; Virtanenc, I. Laminin isoforms in tumor invasion, angiogenesis and metastasis. Semin. Cancer Biol. 2002, 14, 423-430. [CrossRef]

57. Albrengues, J.; Shields, M.A.; Ng, D.; Park, C.G.; Ambrico, A.; Poindexter, M.E.; Upadhyay, P.; Uyeminami, D.L.; Pommier, A.; Küttner, V.; et al. Neutrophil extracellular traps produced during inflammation awaken dormant cancer cells in mice. Science 2018, 361, eaao4227. [CrossRef] [PubMed]

58. Steelman, L.S.; Franklin, R.A.; Abrams, S.L.; Chappell, W.; Kempf, C.R.; Bäsecke, J.; Stivala, F.; Donia, M.; Fagone, P.; Nicoletti, F.; et al. Roles of the Ras/Raf/MEK/ERK pathway in leukemia therapy. Leukemia 2011, 25, 1080-1094. [CrossRef]

59. Hatfield, K.J.; Reikvam, H.; Bruserud, O. The crosstalk between the matrix metalloprotease system and the chemokine network in acute myeloid leukemia. Curr. Med. Chem. 2010, 17, 4448-4461. [CrossRef]

60. Drexler, H.G. The Leukemia-Lymphoma Cell Line Facts Book; Academic Press: San Diego, CA, USA, 2001.

61. Oda, T.; Sekimoto, T.; Kurashima, K.; Fujimoto, M.; Nakai, A.; Yamashita, T. Acute HSF1 depletion induces cellular senescence through the MDM2-p53-p21 pathway in human diploid fibroblasts. J. Cell Sci. 2018, 131, jcs210724. [CrossRef]

62. Mootha, V.K.; Lindgren, C.M.; Eriksson, K.-F.; Subramanian, A.; Sihag, S.; Lehar, J.; Puigserver, P.; Carlsson, E.; Ridderstråle, M.; Laurila, E.; et al. PGC-1 $\alpha$-responsive genes involved in oxidative phosphorylation are coordinately downregulated in human diabetes. Nat. Genet. 2003, 34, 267-273. [CrossRef] [PubMed] 
63. Subramanian, A.; Tamayo, P.; Mootha, V.K.; Mukherjee, S.; Ebert, B.L.; Gillette, M.A.; Paulovich, A.; Pomeroy, S.L.; Golub, T.R.; Lander, E.S.; et al. Gene set enrichment analysis: A knowledge-based approach for interpreting genome-wide expression profiles. Proc. Natl. Acad. Sci. USA 2005, 102, 15545-15550. [CrossRef] [PubMed]

64. Kanda, Y. Investigation of the freely available easy-to-use software "EZR" for medical statistics. Bone Marrow Transplant. 2013, 48, 452-458. [CrossRef] [PubMed]

(c)

(C) 2020 by the authors. Licensee MDPI, Basel, Switzerland. This article is an open access article distributed under the terms and conditions of the Creative Commons Attribution (CC BY) license (http://creativecommons.org/licenses/by/4.0/). 